\title{
PENERAPAN PEMBAGIAN BAGIAN ANAK PEREMPUAN PASAL 176 KOMPILASI HUKUM ISLAM (KHI)
}

\author{
Syuhada' \\ Institut Agama Islam Bani Fattah Jombang, Indonesia \\ E-mail: rokhinsadja@gmail.com
}

\begin{abstract}
The Science of Far'idh is discussing or regulating various matters in the distribution of inheritance to those entitled to receive it from the basic provisions stipulated in the Koran, the sunnah of the Holy Prophet. and ulam agreement '. The object is the distribution of inheritance for heirs who are entitled to receive. The benefit of this knowledge is that it can provide heir rights to inheritance (HP) in accordance with Islamic Sharia guidance based on the Qur'an, Al-Hadit, Al-'Ijmâ 'and Al-Qiyâs. KHI article 176 "If only one part of a daughter gets a share, if two or more people jointly get two parts, and get a daughter together with a boy, so the share of a boy is two to one with daughters. "The part of girls in article $176 \mathrm{KHI}$ receives a separate part with the requirements and bodies that are not accepted by boys. When leaving a son joins, the girl gets one part and the boy gets two parts The share of girls in article $176 \mathrm{KHI}$ receives a third part of the requirements of two or more people and the body does not accept boys When leaving a son joins, the girl gets one part and the boy gets two parts. girls in article $176 \mathrm{KHI}$ join boys and girls get one part while boys get two parts.
\end{abstract}

Keywords: Division, Section Girls 


\section{PENDAHULUAN}

Kewarisan Islam, Ilmu Farầidh atau waris Islam adalah membahas atau mengatur tentang berbagai macam hal dalam pembagian harta peninggalan kepada yang berhak menerimanya atas dasar ketentuan yang telah ditetapakan dalam al-Qur'an, sunnah Nabi saw. dan kesepakatan ulamâ. Pembuat ilmu farầidh atau waris Islam adalah Allah swt. Obyeknya adalah pembagian harta peninggalan kepada ahli waris yang berhak menerima. Faedahnya dengan ilmu tersebut, dapat memberikan hak ahli waris atas harta peninggalan (HP) sesuai dengan tuntunan syariat

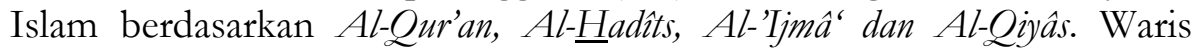
dalam Islam memuat aturan hukum mengenai perpindahan harta milik mayat secara definitif dan bermuatan paket murni dari Allah SWT (tanqifi), itulah sebabnya ayat-ayat al-Qur'an yang menjelaskan tetntang waris tidak banyak, hanya tiga tempat saja yang mengatur secara rinci, detail, dan jelas. Sekalipun demikian al-Qur'an tetap memberikan ruang ijtihâd dalam memahami nash al-Qur'an yang berkaitan dengan penjelasan tetang pembagihan harta peninggalan atau hukum kewarisan.

\section{AYAT-AYAT HUKUM KEWARISAN}

1. Surat An-Nisâ' ayat 11.

a. Menjelasan bagian anak laki-laki dan anak perempuan (walad)

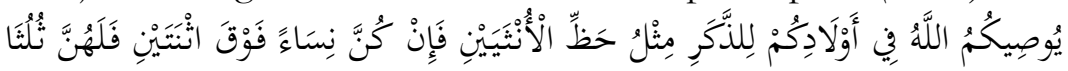

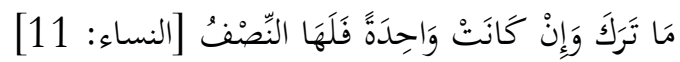

“Allah mensyari'atkan bagimu tentang (pembagian pusaka untuk) anak-anakmu. Yaitu bahagian seorang anak lelaki sama dengan bahagian dua orang anak perempuan. Jika anak itu semuanya perempuan lebih dari dua, maka bagi mereka dua pertiga dari harta yang ditinggalkan. Jika anak perempuan itu seorang saja, maka ia memperoleh setengah harta. (Q.S. An-Nisâ’: 11). ${ }^{2}$

Shahabat Zaid bin Tsâbit r.a. berkata, apabila laki-laki atau perempuan meninggal dan meninggalkan seorang anak perempuan maka bagiannya $1 / 2$ dan jika meninggalkan dua orang anak atau lebih bagian mereka 2/3. ${ }^{3}$ Cucu laki-laki dari anak laki-laki disamakan dengan anak laki-laki, jika mayat tidak meninggalkan anak laki-laki. Dan

1 Muhammad al-Zuhaili, al-Farâ'idh wa alMawârits wa al-washâya, Cet ke-1 (Bairut : Dar al-Qalam at-Thayyib, 2001), 55.

2 Departemen Agama Republik Indonesia, al-Qur'an dan Terjemabnya (Jakarta : Yayasan Penyelenggara Penterjemah/Pentafsir al-Qur'an, 1971), 116

3 al-Bukhâri, Abi Abdillah M. bin Ismâ'il mtn shabih al-Bukhâri,(singapura, t.th) 165 
cucu perempuan dari anak laki-laki disamakan dengan anak perempuan, jika mayat tidak meninggalkan anak perempuan. Sebab kata walad mencakup anak, cucu, dan cicit. Sebagaimana kesepakatan 'ulamâ' fiqih.

b. Bagian orang tua (Bapak-Ibu).

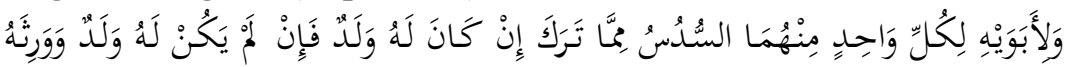

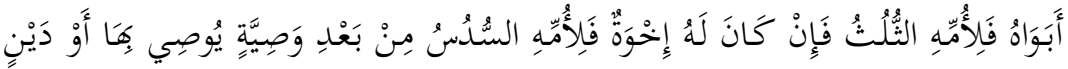

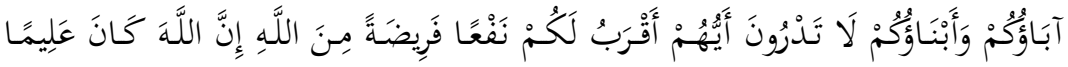

$$
\begin{aligned}
& \text { حَكِيمًا [النساء: 11 }
\end{aligned}
$$

"Dan untuk dua orang ibu bapak, bagi masing-masing seperenam dari harta yang ditinggalkan, jika yang meninggal itu mempunyai anak, jika orang yang meninggal tidak mempunyai anak dan ia diwarisi oleh ibu-bapaknya (saja), maka ibunya mendapat sepertiga, jika yang meninggal itu mempunyai beberapa saudara, maka ibunya mendapat seperenam, (pembagian-pembagian tersebut di atas) sesudah dipenuhi wasiat yang ia buat atau (dan) sesudah dibayar hutangnya. (Tentang) orang tuamu dan anakanakmu, kamu tidak mengetahui siapa di antara mereka yang lebih dekat (banyak) manfa'atnya bagimu. Ini adalah ketetapan dari Allah. Sesungguhnya Allah Maha Mengetahui lagi Maha Bijaksana. (Q.S. An-Nisâ': 11)."4

2. Surat An-Nisâ' ayat 12 .

a. Menjelaskan bagian suami/duda.

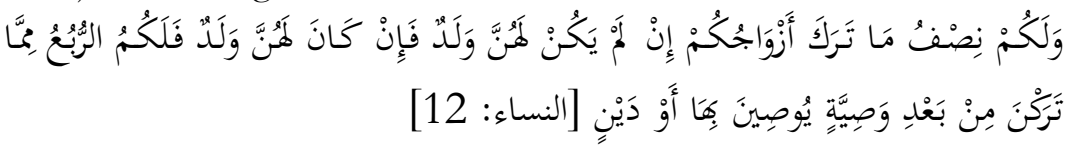
"Dan bagimu (suami-suami) seperdua dari harta yang ditinggalkan oleh istri-istri mu, jika mereka tidak mempunyai anak, jika istri-istrimu itu mempunyai anak, maka kamu mendapat seperempat dari harta yang ditinggalkannya sesudah dipenuhi wasiat yang mereka buat atau (dan) sesudah dibayar hutangnya. (Q.S. An-Nisâ': 12)."5

b. Bagian janda atau beberapa janda.

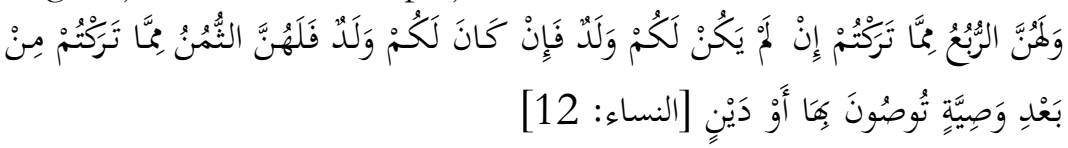

${ }^{4}$ Departemen agama, Al-Qur'an, 117.

${ }^{5}$ Ibid., 
"Para istri memperoleh seperempat dari harta yang kamu tinggalkan, jika kamu tidak mempunyai anak, jika kamu mempunyai anak, maka para istri mendapat seperdelapan dari harta yang kamu tinggalkan sesudah dipenuhi wasiat yang kamu buat atau (dan) sesudah dibayar hutang-hutangmu. (Q.S. AnNisâ': 12)." "6

c. Bagian saudara seibu (laki-laki dan perempuan).

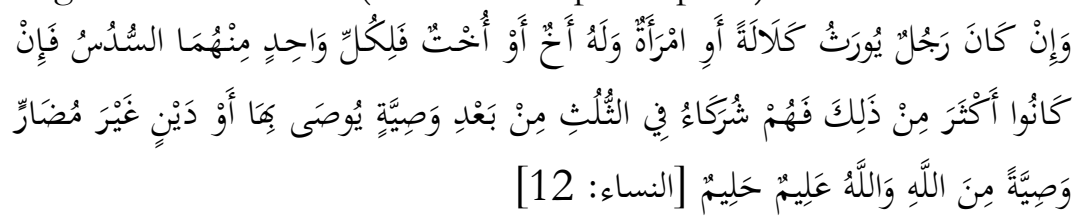

"Jika seorang mati, baik laki-laki maupun perempuan yang tidak meninggalkan ayah dan tidak meninggalkan anak, tetapi mempunyai seorang saudara laki-laki (seibu saja) atau seorang saudara perempuan (seibu saja) maka bagi masing-masing dari kedua jenis saudara itu seperenam harta. Tetapi jika saudarasaudara seibu itu lebih dari seorang, maka mereka bersekutu dalam yang sepertiga itu, sesudah dipenuhi wasiat yang dibuat olehnya dengan tidak memberi mudharat (kepada ahli waris). (Allah menetapkan yang demikian itu sebagai) sebagai syari'at yang benar-benar dari Allah, dan Allah Maha Mengetahui lagi Maha Penyantun. (Q.S. An-Nisâ': 12)."7

3. Surat An-Nisâ' ayat 176 .

Menjelaskan bagian saudara sekandung (laki-laki dan perempuan)

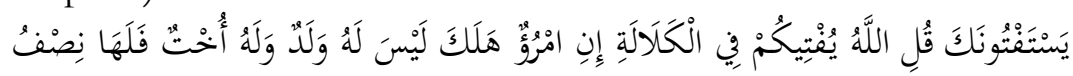

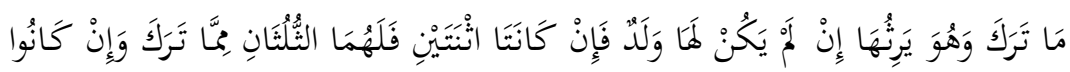

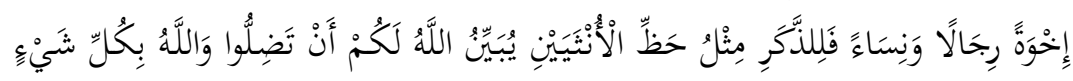

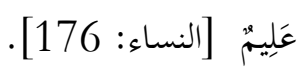

"Mereka mintak fatwa kepadamu tentang (kalâlab). Katakanlah "Allah memberi fatwa kepadamu tentang kalala (yaitu): Jika seorang meninggal dunia, dan ia tidak mempunyai anak dan mempunyai saudara perempuan, maka bagi saudaranya yang perempuan itu seperdua dari harta yang ditinggalkannya, dan saudaranya yang laki-laki mempusakai (seluruh harta saudara 
perempuan), jika ia tidak mempunyai anak; tetapi jika saudara perempuan itu dua orang, maka bagi keduanya dua pertiga dari harta yang ditinggalkan oleh yang meninggal. Dan jika mereka (ahli waris itu terdiri dari) saudara-saudara laki-laki dan perempuan, maka bagian seorang saudara laki-laki sebanyak bahagian dua orang saudara perempuan." Allah menerangkan (hukum ini) kepadamu, supaya kamu tidak sesat. Dan Allah Maha Mengetahui segala sesuatu. (Q.S. An-Nisâ’’ 176)."”

\section{HADITS-HADITS MAWARITS}

1. Tata cara membagi warisan. Penerima bagian pasti didahulukan setelah itu baru 'ashabah

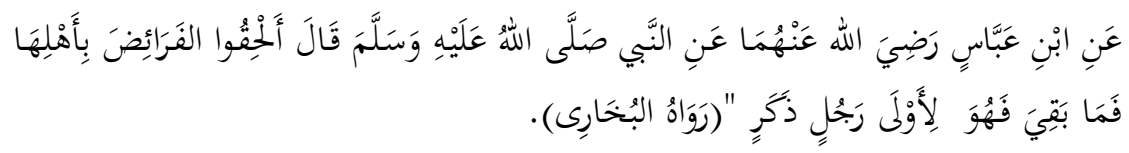

Dari Ibnu Abbas ra. dari Nabi saw. "Nabi saw bersabda : Berikanlah bagian-bagian pasti kepada ahli waris yang berhak. Sesudah itu sisanya diutamakan (untuk) orang laki-laki ('asabab)". (HR. alBukhâri). ${ }^{9}$

2. Orang muslim tidak diperbolehkan mewaris harta peninggalan orang kafir dan sebaliknya.

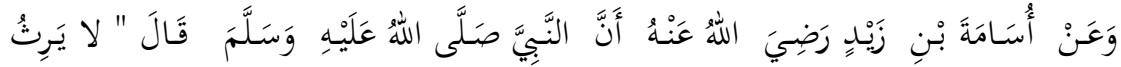

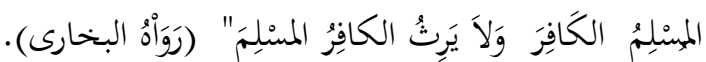

"Dari 'Usâmah bin Zaid r.a. Rasulullah saw. bersabda "Orang muslim tidak berhak mewarisi orang kafir, dan orang kafir tidak berhak mewarisi orang muslim". (HR. Imam Bukhâri ${ }^{10}$

3. Cucu perempuan mendapat bagian $1 / 6$ untuk melengkapi bagian $1 / 2$ yang diterima anak perempuan sehingga bagian anak perempuan dan cucu perempuan menjadi 2/3. Dan saudara perempuan sekandung sebagai 'ashabah ma' al ghair jika bersama dengan anak perempuan atau cucu perempuan.

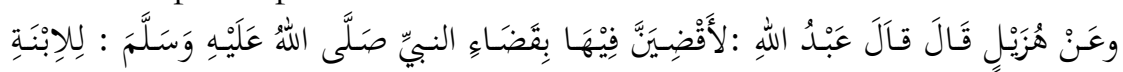

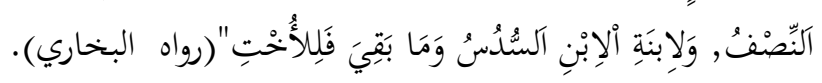


"Dari Huzail berkata, Abdullah berkata, saya pasti akan menghukumi masalah (pembagaian harta peninggalan) sebagaimana Nabi saw. menghukumi, untuk bagian anak perempuan setengah $(1 / 2)$ sedangkan bagiannya cucu perempuan adalah seperenam, lalu sisanya diberikan pada saudara perempuan (sekandung/seayah)." (HR. Imam Bukhâri). ${ }^{11}$

4. Maksimal wasiat dan radd

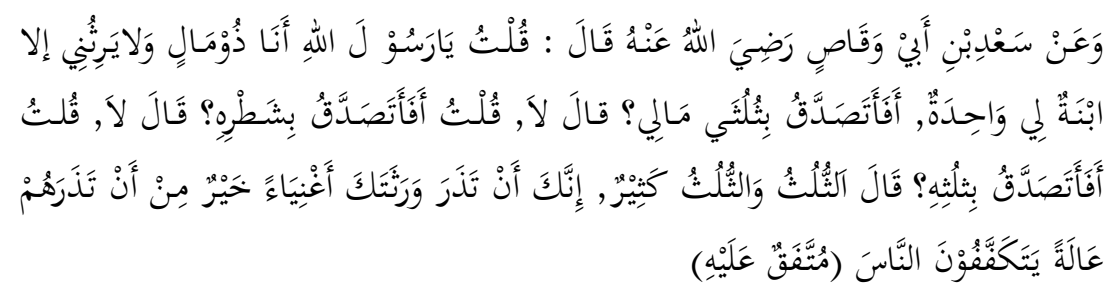

"Dari Sa'ad bin Abi Waqâsh ra. berkata aku berkata wahai Rasul Aku adalah orang kaya dan tidak mempunyai ahli waris kecuali seorang anak perempuan, bolehkah aku bersedekah dengan dua pertiga hartaku? Rasul menjawab: jangan. Aku berkata: separuhnya? Rasul menjawab: jangan. Aku berkata: sepertiga? Rasul menjawab: sepertiga sudah banyak. Sesungguhnya bagimu akan lebih baik meninggalkan pewarismu kaya dari pada meninggalkan mereka dalam keadaan miskin dan meminta belas kasihan kepada orang lain." (HR.Bukhâri Muslim). ${ }^{12}$

5. Hukum Mempelajari dan Mengajar Ilmu Farâ’idh

Hukum mempelajari dan mengajar ilmu farâ'idh adalah fardbu'ain yaitu kewajiban yang harus dilakukan oleh setiap individu. Berdasarkan redaksi hadîts yang menggunakan bentuk perintah ('amar) yaitu hadîts yang diriwatkan oleh Ibn Mas'ûd ra.:

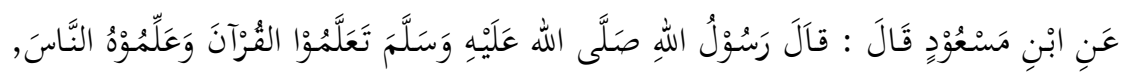

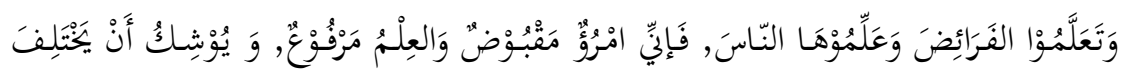

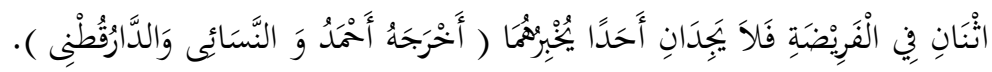

"Dari ibnu Mas'ûd berkata, Rasulullah saw. bersabda: "Pelajarilah oleh kalian Al-Qur'an dan ajarkanlah kepada orang lain, dan pelajarilah ilmu farầidh dan ajarkanlah kepada orang lain, karena sesungguhnya aku adalah orang yang bakal terenggut (meninggal),

${ }^{11}$ Ibid., 167

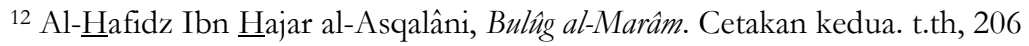


sedangkan ilmu faraidl akan hilang. Hampir saja dua orang yang berselisih tentang pembagian harta warisan tidak menjumpai seorang pun yang dapat memberikan fatwa kepada mereka berdua" (HR. Ahmad, An-Nasâ'i dan Ad-Dâr qutni). ${ }^{13}$

Kata "ta'allamû dan 'allimû al-farâ'idh" menggunakan shîghat 'amr. Dalam kaidah ushul fiqib bentuk 'amr pada yang diperintah adalah wajib. Dan juga dapat berhukum fardh kifâyah, yaitu kuwajiban yang dibebankan atas semua mukallaf. Namun, tolak ukurnya ada pada target capaian, bukan pada respon individu. Bila target beban sudah tercapai, dalam arti sudah dikerjakan oleh seseorang dari kelompok mereka, maka sebagian orang yang termasuk kelompok mereka dianggap cukup (kifâyah).

Al-Qur'an merupakan acuan pertama hukum dan penentuan pembagian waris. Bahkan tidak ada ketentuan hukum lain yang sebegitu baku dalam al-Qur'an seperti halnya dalam persoalan hukum waris. Hanya saja, dalam teks al-Qur'an ketentuan waris sangat terbatas dan global sekali, peran hadits disampng sebagai bayân Al-Qur'an juga ikut menetapkan aturan dan juga menjelaskan tentang tata cara membagi harta peninggalan (HP). Meski demikian ruang ijtihâd tetap terbuka untuk pembagian harta peninggalan (HP), apalagi munculnya kasus-kasus pasca wafatnya baginda Rasulullah SAW, seperti kasus Gharrawain, Musytarakah, Akdariyyah dll.

Islam memandang harta adalah milik Allah SWT semata, sedangkan manusia ditunjuk sebagai penguasanya. Begitu orang yang diamanati dan yang dititipi itu meninggal dunia, maka, harta kembali menjadi milik Allah swt secara otomatis. Oleh karena itu Allah swt. berhak ikut mengatur harta yang ditinggalkan oleh pemiliknya, paling tidak dengan sifat rahmân kepada mahlûq-Nya Allah swt mewakili mayat sebagai pemilik yang sudah tidak berdaya. Aturan yang ditetapkan oleh Allah swt adalah diberikan kepada keluarga yang ditunjuk dengan aturan wahyu. Dalam Fiqh Islam dikenal empat sebab milik yaitu; al-'aqd (transaksi), tawallud min al-milk (perkembangan harta milik) dan ihrâz al-mubahat (eksplorasi kepemilikan umum), dan al-khalafiyah/irtsun (penerus kepemilikan atau warisan). Zakariya al-Anshari menyebut ada sebab umum dan ada pula sebab khusus dalam hal mendapatkan harta secara halâl dari sisi khalafiyah (penerusan kepemilikan) dengan media pewarisan. Sebab umum dimana seseorang berhak mendapat warisan adalah beragama Islam. ${ }^{14}$ Sedangkan

\footnotetext{
13 Asy-Syaukani, Nail al-'Authâr, juz 6, (Bairut ; Dar al-Fikr, t.th) 168.

14 Zakariya al-Ansari, Sharh al-Tahrir. (Surabaya: Maktabat Salim b. Sa'ad b. Nabhan, t.th), 86-87.
} 
sebab khusus cara mendapatkan harta secara halâl dalam khalafiyah (penerusan kepemilikan) dengan media pewarisan adalah :

a. Hubungan kerabat khusus, yang mempunyai hubungan darah dengan mayat.

b. Melangsungkan akad pernikahan secara sah menurut syari'at Islam

c. waris wala' atau mendapatkan warisan karena memerdekakan budak, disebut juga dengan nasab bukmi, ${ }^{15}$

\section{KHI PASAL 176}

KHI pasal 176 "Anak perempuan bila hanya seorang ia mendapat separoh bagian, bila dua orang atau lebih mereka bersama-sama mendapatkan dua pertiga bagian, dan apabila anak perempuan bersamasama dengan anak laki-laki, maka bagian anak laki-laki adalah dua berbanding satu dengan anak perempuan”.

Anak perempuan dalam KHI pasal 176 adalah keturunan yang mempunya hubungan darah dengan mayat, yaitu keturunan pertama dari pasangan suami istri atau keturunan dari seorang ibu. Anak perempuan tersebut beragama Islam pada waktu mayat meninggal dunia, dan tidak terhalang menjadi ahli waris dengan putusan hakim yang telah mempunyai kekuatan hukum yang tetap, dihukum karena ; dipersalahkan telah membunuh atau mencoba membunuh atau menganiayah berat pada pewaris dan dipersalahkan secara memfitna telah mengajukan pengaduan bahwa pewaris telah melakukan suatu kejahatan yang diancam dengan hukuman 5 tahun penjara atau hukuman yang lebih berat.

Sedangkan penyebutan bagian pasti; separoh bagian, dua pertiga bagian, dan bagian anak laki-laki adalah dua berbanding satu dengan anak perempuan, dipahami bahwa bagian pasti tersebut atau dua bagian berbanding satu bagian tersebut adalah dari seluruh harta peninggalan (HP) mayat/pewaris, tentunya setelah ditunaikan untuk perawatan mayat (tajhî al-mait) secara wajar, tidak diperbolehkan berlebihan, ditunaikan melunasi hutang-hutangnya mayat, baik hutang kepada Allah SWT seperti hutang melaksanakan ibadah haji, maupun hutang kepada sesama manusia, dan menunaikan wasiat mayat (pewaris) tentu saja wasiat tersebut tidak diperbolehkan melebihi sepertiga dari harta peninggala (HP) mayat. Sesuai dengan pendapat mayoritas para fuqaha' bahwa maksimal wasiat adalah $1 / 3$ sedangkan $2 / 3$ nya adalah hak untuk semua ahli waris yang ditinggalkan. Seandainya wasiat itu besarnya melebihi sepertiganya dari harta peninggalan maka, kelebihan tersebut diserahkan kepada ahli warisnya, seandainya ahliwaris meristua ya dilaksanakan dan seandainya tidak, ya tidak.

${ }^{15}$ Ahmad 'Abd al-Jawad, Ushul Tlm al-Mawarith, Cet. II, (Beirut : Da>r al-Jil, 1986), 1-2. 
Anak perempuan yang dimaksud dalam KHI pasal 176 adalah anak perempuan ketika orang tuanya meninggal dunia ia masih hidup, sehingga ia dikatakan mewarisi harta peninggalan (HP) dari orang tuanya yang sudah meninggal.

\section{PEMBAHASAN}

\section{Surat An-Nisâ' ayat 11}

Menjelasan bagian anak perempuan dan anak laki-laki (walad) adalah:

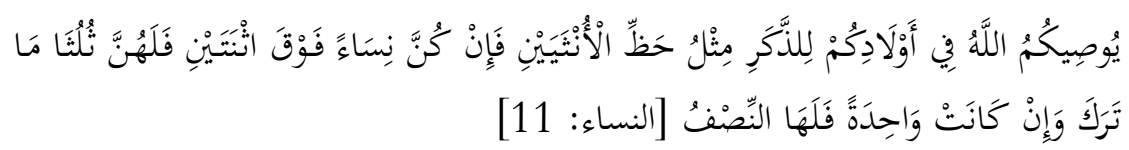

"Allah mensyari'atkan bagimu tentang (pembagian pusaka untuk) anak-anakmu. Yaitu bahagian seorang anak lelaki sama dengan bahagian dua orang anak perempuan. Jika anak itu semuanya perempuan lebih dari dua, maka bagi mereka dua pertiga dari harta yang ditinggalkan. Jika anak perempuan itu seorang saja, maka ia memperoleh setengah harta. (Q.S. An-Nisâ': 11). ${ }^{16}$

Shahabat Zaid bin Tsâbit r.a. berkata, apabila laki-laki atau perempuan meninggal dan meninggalkan seorang anak perempuan maka bagiannya $1 / 2$ dan jika meninggalkan dua orang anak atau lebih bagian mereka 2/3. ${ }^{17}$ Cucu laki-laki dari anak laki-laki disamakan dengan anak laki-laki, jika mayat tidak meninggalkan anak laki-laki. Dan cucu perempuan dari anak laki-laki disamakan dengan anak perempuan, jika mayat tidak meninggalkan anak perempuan. Sebab kata walad mencakup anak, cucu, dan cicit. Sebagaimana kesepakatan 'ulamâ' fiqih.

\section{Contoh-Contoh Kasus}

\section{Anak perempuan mendapat separoh bagian}

Anak perempuan mendapat separoh bagian, jika seorang dan pewaris tidak meninggalkan anak laki-laki

1. Contoh: Anak perempuan mendapat separoh bagian

\begin{tabular}{|c|c|c|c|c|}
\hline \multicolumn{3}{|c|}{ Ahli waris } & \multicolumn{2}{|c|}{$\mathrm{AM}: 8$} \\
\hline 1 & زَوْجَةٌُ & Istri & $1 / 8$ & 1 bagian \\
\hline
\end{tabular}

16 Departemen Agama Republik Indonesia, al-Qur'an dan Terjemahnya (Jakarta : Yayasan Penyelenggara Penterjemah/Pentafsir al-Qur'an, 1971), 116

17 al-Bukhâri, Abi Abdillah M. bin Ismâ'il mtn shahỉ al-Bukhâri,(singapura, t.th) 165 


\begin{tabular}{|c|c|c|c|c|}
\hline 2 & بِنْتُ & Anak pr. & $1 / 2$ & 4 bagian \\
\hline 2 & 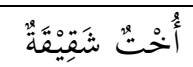 & Saudara pr & Sisa & 3 bagian \\
\hline
\end{tabular}

\section{Penjelasan :}

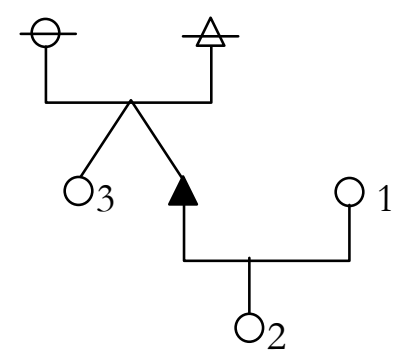

Istri mendapat seperdelapan bagian dan mendapat satu bagian. Anak perempuan mendapat separoh bagian sebab seorang dan mendapat empat bagian.

\section{Saudara perempuan mendapat sisa dan mendapat tiga bagian.}

2. Contoh: Anak perempuan mendapat separoh bagian

\begin{tabular}{|c|c|c|c|c|}
\hline \multicolumn{3}{|c|}{ Ahli waris } & \multicolumn{2}{|c|}{ AM : 8} \\
\hline 1 & زَوْجَةُّ & Istri & $1 / 8$ & 1 bagian \\
\hline 2 & بِنْت & Anak pr. & $1 / 2$ & 4 bagian \\
\hline 3 & أُخْتُ قُهَ & Saudara pr. & Sisa & 3 bagian \\
\hline
\end{tabular}

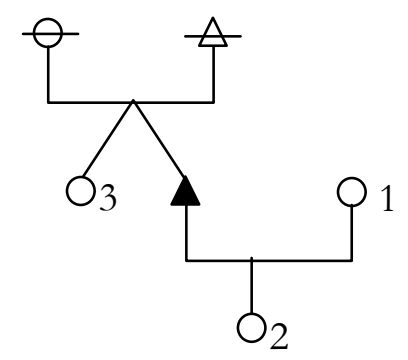

\section{Penjelasan :}

1. Istri mendapat bagian $1 / 8$ dan mendapatkan satu bagian.

2. Anak perempuan mendapat $1 / 2$ sebab seorang dan mendapat empat bagian.

3. Saudara pr. mendapat sisa dan menerima tiga bagian. 
Misalkan harta peninggalan Rp 24.000.000 maka pembagiannya adalah : $\frac{H P: R p 24.000 .000}{A M: 8}=R p 3.000 .000$

\begin{tabular}{|c|c|c|c|}
\hline \multicolumn{2}{|c|}{ Ahli waris } & \multicolumn{2}{|c|}{ Bagian yang diterima oleh ahli waris } \\
\hline 1 & زَزوَْحةُ & 1 bagian x Rp 3.000 .000 & Rp $\quad 3.000 .000$ \\
\hline 2 & بِنْتُتُ & 4 bagian x Rp 3.000 .000 & Rp 12.000.000 \\
\hline 3 & أُخْتِتُ قَه & 3 bagian x Rp 3.000 .000 & 9.000 .000 \\
\hline & & Jumlah & Rp 24.000.000 \\
\hline
\end{tabular}

3. Contoh: Anak perempuan mendapat separoh bagian

\begin{tabular}{|c|c|c|c|c|}
\hline \multicolumn{3}{|c|}{ Ahli waris } & \multicolumn{2}{|c|}{ AM : 4} \\
\hline 1 & زَوَْْجُ & Suami & $1 / 4$ & 1 bagian \\
\hline 2 & نِنْتُتُ & Anak pr. & $1 / 2$ & 2 bagian \\
\hline 3 & أُخْتِ قُه & Cucu laki-laki & Sisa & 1 bagian \\
\hline
\end{tabular}

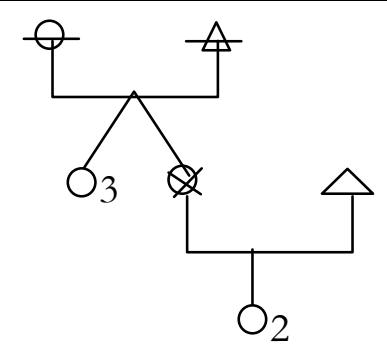

\section{Penjelasan :}

1. Suami mendapat bagian $1 / 8$ sebab ada anak dan mendapat satu bagian.

2. Anak perempuan mendapat $1 / 2$ sebab seorang dan mendapat dua bagian.

3. Saudara pr. mendapat sisa dan menerima tiga bagian.

Misalkan harta peninggalan Rp 24.000.000 maka pembagiannya adalah : $\frac{H P: R p 24.000 .000}{A M: 4}=R p 6.000 .000$

\begin{tabular}{|c|c|c|c|}
\hline \multicolumn{2}{|c|}{ Ahli waris } & \multicolumn{2}{|c|}{ Bagian yang diterima oleh ahli waris } \\
\hline 1 & زَوْْجُج & 1 bagian x Rp 6.000 .000 & Rp $\quad 6.000 .000$ \\
\hline 2 & بِنْتُ ت & 2 bagian x Rp 6.000 .000 & Rp 12.000.000 \\
\hline
\end{tabular}




\begin{tabular}{|l|l|l|l|}
\hline 3 & أُخْنْ & 1 bagian x Rp 6.000.000 & Rp 6.000 .000 \\
\hline \multicolumn{2}{|c|}{ Jumlah } & Rp 24.000.000 \\
\hline
\end{tabular}

4. Contoh: Anak perempuan mendapat separoh bagian

\begin{tabular}{|c|c|c|c|c|}
\hline \multicolumn{3}{|c|}{ Ahli waris } & \multicolumn{2}{|c|}{ Asal Masalah (AM) : 24} \\
\hline 1 & زَوَجَجة & Istri & $1 / 8$ & 3 bagian \\
\hline 2 & بِنْتُ & Anak perempuan & $1 / 2$ & 12 bagian \\
\hline 3 & أَبَّْ & Bapak & $1 / 6+$ Sisa & 9 bagian \\
\hline
\end{tabular}

\section{Penjelasan :}

1. Istri mendapat bagian $1 / 8$ dan menerima tiga bagian.

2. Anak perempuan mendapat bagian $1 / 2$ dan menerima dua belas bagian

3. Bapak mendapat bagian $1 / 6$ dan sisa dan menerima sembilan bagian.

Misalkan harta peninggalan Rp 24.000.000 maka pembagiannya adalah : $\frac{H P: R p 24.000 .000}{A M: 24}=R p 1.000 .000$

\begin{tabular}{|c|c|c|c|}
\hline \multicolumn{2}{|c|}{ Ahli waris } & \multicolumn{2}{|c|}{ Bagian yang diterima oleh ahli waris } \\
\hline 1 & زَوْجَحة & 3 bagian x Rp 1.000 .000 & 3.000 .000 \\
\hline 2 & بِنْتَن & 12 bagian x Rp 1.000 .000 & Rp 12.000 .000 \\
\hline 3 & أَبُ & 9 bagian x Rp 1.000 .000 & 9.000 .000 \\
\hline & & Jumlah & Rp 24.000 .000 \\
\hline
\end{tabular}

5. Contoh: Anak perempuan mendapat separoh bagian

\begin{tabular}{|c|c|c|c|c|}
\hline \multicolumn{3}{|c|}{ Ahli waris } & \multicolumn{2}{|c|}{ Asal Masalah (AM): 12} \\
\hline 1 & زَوْْجُ & Suami & $1 / 4$ & 3 bagian \\
\hline 2 & بِنْتُ & Anak perempuan & $1 / 2$ & 6 bagian \\
\hline 3 & أَبَُّ & Bapak & $1 / 6+$ Sisa & 3 bagian \\
\hline
\end{tabular}

\section{Penjelasan :}

1. Suami mendapat bagian $1 / 4$ dan mendapat tiga bagian. 
2. Anak perempuan mendapat bagian $1 / 2$ dan mendapat enam bagian.

3. Bapak mendapat $1 / 6$ dan sisa dan menerima tiga bagian.

Misalkan harta peninggalan Rp 24.000.000 maka pembagiannya adalah : $\frac{H P: R p 24.000 .000}{A M: 12}=R p 2.000 .000$

\begin{tabular}{|c|c|c|c|}
\hline \multicolumn{2}{|c|}{ Ahli waris } & \multicolumn{2}{|c|}{ Bagian yang diterima oleh ahli waris } \\
\hline 1 & زَوْْجُ & 3 bagian $x$ Rp 2.000 .000 & Rp $\quad 6.000 .000$ \\
\hline 2 & بِنْتُ & 6 bagian x Rp 2.000 .000 & Rp 12.000 .000 \\
\hline 3 & أَبْبٌ & 3 bagian x Rp 2.000 .000 & 6.000 .000 \\
\hline & & Jumlah & Rp 24.000 .000 \\
\hline
\end{tabular}

c. Contoh-contoh kasus anak perempuan mendapat dua pertiga bagian

Anak perempuan mendapat dua pertiga bagian, jika dua orang atau lebih sdan pewaris tidak meninggalkan anak laki-laki

1. Contoh: Bagian dua anak perempuan mendapat dua pertiga bagian

\begin{tabular}{|c|c|c|c|c|}
\hline \multicolumn{2}{|c|}{ Ahli waris } & \multicolumn{3}{|c|}{ Asal Masalah (AM) : 12} \\
\hline 1 & زَوَجْجُ & $1 / 4$ & 3 & 3 bagian \\
\hline 2 & بِنْتُ & \multirow{2}{*}{$2 / 3$} & \multirow{2}{*}{8} & 4 bagian \\
\hline 3 & بَنْتُ & & & 4 bagian \\
\hline 4 & أُخْتِتُ شَقِيْقَةُُّ & Sisa & 1 & 1 bagian \\
\hline
\end{tabular}

\section{Penjelasan :}

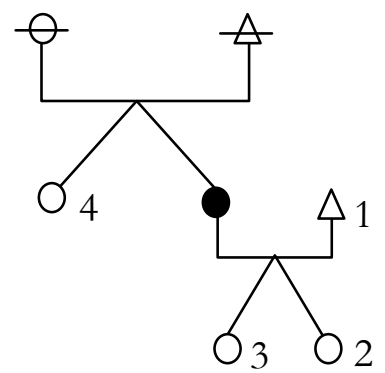

1. Bagian suami seperempat bagian mendapat tiga bagian

2. Dua anak perempuan dua pertiga bagian mendapat@empat bagian

3. Saudara pr. sekandung sisa mendapat satu bagian. 
Misalkan harta peninggalan Rp 24.000.000 maka pembagiannya adalah : $\frac{H P: R p 24.000 .000}{A M: 12}=R p 2.000 .000$

\begin{tabular}{|c|c|c|c|}
\hline \multicolumn{2}{|c|}{ Ahli waris } & \multicolumn{2}{|c|}{ Bagian yang diterima oleh ahli waris } \\
\hline 1 & زَوْْجْ & 3 bagian x Rp 2.000 .000 & Rp $\quad 6.000 .000$ \\
\hline 2 & 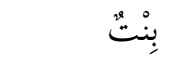 & 4 bagian x Rp 2.000 .000 & Rp $\quad 8.000 .000$ \\
\hline 3 & بِنْتُ & 4 bagian x Rp 2.000 .000 & Rp $\quad 8.000 .000$ \\
\hline 4 & 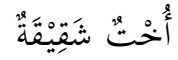 & 1 bagian x Rp 2.000 .000 & $\mathrm{Rp} \quad 2.000 .000$ \\
\hline & & Jumlah & Rp 24.000 .000 \\
\hline
\end{tabular}

2. Contoh: Bagian dua anak perempuan mendapat dua pertiga bagian

\begin{tabular}{|c|c|c|c|c|c|}
\hline \multicolumn{3}{|c|}{ Ahli waris } & \multicolumn{3}{|c|}{ Asal Masalah (AM) : 6} \\
\hline 1 & أَبٌْ & Bapak & 1/6 dan Sisa & $1+1$ & 2 bagian \\
\hline 2 & بِنْتُ & Anak pr. & \multirow{2}{*}{$2 / 3$} & 4 & 2 bagian \\
\hline 3 & بِنْتِ & Anak pr. & & & 2 bagian \\
\hline
\end{tabular}

\section{Penjelasan :}

Bapak mendapat bagian $1 / 6+$ sisa dan mendapat dua bagian. Dua anak perempuan mendapat $2 / 3$ dan masing-masing mendapat dua bagian.

3. Contoh: Anak perempuan mendapat dua pertiga bagian

\begin{tabular}{|c|c|c|c|c|c|}
\hline \multicolumn{3}{|c|}{ Ahli waris } & \multicolumn{3}{|c|}{ Asal Masalah (AM): 24} \\
\hline 1 & زَوْْجَةُ & Istri & $1 / 8$ & 3 & 3 bagian \\
\hline 2 & بِنْتُ & \multirow{2}{*}{ Anak pr. } & \multirow{2}{*}{$2 / 3$} & \multirow{2}{*}{16} & 8 bagian \\
\hline 3 & بنْتَت & & & & 8 bagian \\
\hline 4 & أُخْتِتُ شَقَقِيََْةُّ & Saudara pr. & sisa & 5 & 5 bagian \\
\hline
\end{tabular}

\section{Penjelasan :}

Istri mendapat bagian $1 / 8$ dan menerima tiga bagian. Dua anak perempuan mendapat bagian $2 / 3$ dan menerima enam belas bagian 
dan saudara perempuan mendapat bagian sisa dan menerima sembilan bagian.

Misalkan harta peninggalan $\mathrm{Rp} 24.000 .000$ maka pembagiannya adalah $: \frac{H P: R p 24.000 .000}{A M: 24}=R p 1.000 .000$

\begin{tabular}{|c|c|c|c|}
\hline \multicolumn{2}{|c|}{ Ahli waris } & \multicolumn{2}{|c|}{ Bagian yang diterima oleh ahli waris } \\
\hline 1 & زَوْجَةٌٌ & 3 bagian x Rp 1.000 .000 & Rp 3.000 .000 \\
\hline 2 & بِنْتِ & 8 bagian x Rp 1.000 .000 & Rp 8.000 .000 \\
\hline 3 & بِنْتُ & 8 bagian x Rp 1.000 .000 & Rp 8.000 .000 \\
\hline 4 & أُخْنت شُقِقِيْقَةُّة & 5 bagian $x$ Rp 1.000 .000 & Rp 5.000 .000 \\
\hline & & Jumlah & Rp 24.000.000 \\
\hline
\end{tabular}

4. Contoh: Anak perempuan mendapat dua pertiga bagian

\begin{tabular}{|c|c|c|c|c|c|}
\hline \multicolumn{3}{|c|}{ Ahli waris } & \multicolumn{3}{|c|}{ Asal Masalah (AM): 24} \\
\hline 1 & 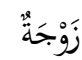 & Istri & $1 / 8$ & 3 & 3 bagian \\
\hline 2 & أَبَُْ & Bapak. & $1 / 6$ dan sisa & 5 & 5 bagian \\
\hline 3 & بِنْتُ & Anak pr & \multirow{2}{*}{$2 / 3$} & \multirow{2}{*}{16} & 8 bagian \\
\hline 4 & 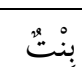 & Anak pr & & & 8 bagian \\
\hline
\end{tabular}

\section{Penjelasan :}

Istri mendapat bagian $1 / 8$ dan menerima tiga bagian. Dua anak perempuan mendapat bagian $2 / 3$ dan menerima enam belas bagian dan saudara perempuan mendapat bagian sisa dan menerima sembilan bagian.

Seandainya HP Rp 24.000.000, maka istri mendapat Rp 3.000.000, bapak mendapat Rp 5.000.000, dan masing-masing anak perempuan mendapatkan bagian sebesar Rp 8.000.000 = Rp 16.000.0000. Jumlah yang diterima oleh masing-masing ahli waris adalah $\mathrm{Rp}$ 24.000.000, sesuai dengan HP.

5. Contoh: Anak perempuan mendapat dua pertiga bagian

\begin{tabular}{|c|c|c|c|c|c|}
\hline \multicolumn{3}{|c|}{ Ahli waris } & \multicolumn{3}{|c|}{ Asal Masalah (AM): 12} \\
\hline 1 & زَوَْْجُ & suami & $1 / 4$ & 3 & 3 bagian \\
\hline
\end{tabular}




\begin{tabular}{|c|c|c|c|c|c|}
\hline 2 & بِنْتُ & \multirow{2}{*}{ Anak pr. } & \multirow{2}{*}{$2 / 3$} & \multirow{2}{*}{8} & 4 bagian \\
\hline 3 & بِنْتُ & & & & 4 bagian \\
\hline 4 & 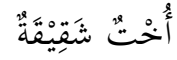 & Saudara pr. & sisa & 1 & 1 bagian \\
\hline
\end{tabular}

\section{Penjelasan :}

Suami mendapat bagian 1/4 dan menerima tiga bagian. Dua anak perempuan mendapat bagian $2 / 3$ dan menerima delapan bagian dan saudara perempuan mendapat bagian sisa dan menerima 1 bagian.

Misalkan harta peninggalan Rp 24.000.000 maka pembagiannya adalah : $\frac{H P: R p 24.000 .000}{A M: 12}=R p 2.000 .000$

\begin{tabular}{|c|c|c|c|}
\hline \multicolumn{2}{|c|}{ Ahli waris } & \multicolumn{2}{|c|}{ Bagian yang diterima oleh ahli waris } \\
\hline 1 & زَوْْجْ & 3 bagian x Rp 2.000 .000 & Rp 6.000 .000 \\
\hline 2 & بِنْتُ & 4 bagian x Rp 2.000 .000 & Rp 8.000 .000 \\
\hline 3 & بِنْتُ & 4 bagian x Rp 2.000 .000 & Rp 8.000 .000 \\
\hline 4 & 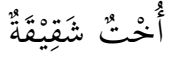 & 1 bagian $x$ Rp 2.000 .000 & $\mathrm{Rp} \quad 2.000 .000$ \\
\hline & & Jumlah & Rp 24.000 .000 \\
\hline
\end{tabular}

6. Contoh: Anak perempuan mendapat dua pertiga bagian

\begin{tabular}{|c|c|c|c|c|c|}
\hline \multicolumn{3}{|c|}{ Ahli waris } & \multicolumn{3}{|c|}{ Asal Masalah (AM): 12} \\
\hline 1 & زَوْْجُ & Suami & $1 / 4$ & 3 & 3 bagian \\
\hline 2 & بِنْتُ & \multirow{2}{*}{ Anak pr. } & \multirow{2}{*}{$2 / 3$} & \multirow{2}{*}{8} & 4 bagian \\
\hline 3 & نبنتِت & & & & 4 bagian \\
\hline 4 & أُخْتِتُ لِأَبْ & Saudara pr. sebapak & sisa & 1 & 1 bagian \\
\hline
\end{tabular}

\section{Penjelasan :}

Suai mendapat bagian $1 / 4$ dan menerima tiga bagian. Dua anak perempuan mendapat bagian $2 / 3$ dan menerima de bagian dan saudara perempuan seayah mendapat bagian sisa dan menerima satu bagian.

Seandainya HP Rp 24.000.000, maka istri mendapat Rp 6.000.000, masing-masing anak perempuan mendapatkan bagian sebesar Rp 8.000.000 $=$ Rp 16.000.0000. dan saudara pr. Sebapak mendapat Rp 
2.000.000, Jumlah yang diterima oleh masing-masing ahli waris adalah Rp 24.000.000, sesuai dengan HP.

7. Contoh: Anak perempuan mendapat dua pertiga bagian

\begin{tabular}{|c|c|c|c|c|c|}
\hline \multicolumn{3}{|c|}{ Ahli waris } & \multicolumn{3}{|c|}{ Asal Masalah (AM): 12} \\
\hline 1 & زَوْْجْ & suami & $1 / 4$ & 3 & 3 bagian \\
\hline 2 & بِنْتُ & \multirow{2}{*}{ Anak pr. } & \multirow{2}{*}{$2 / 3$} & \multirow{2}{*}{8} & 4 bagian \\
\hline 3 & بـنتـت & & & & 4 bagian \\
\hline 4 & أُ نُ شَقَقْقِقُ & Saudara $\mathrm{lk}$ & sisa & 1 & 1 bagian \\
\hline
\end{tabular}

\section{Penjelasan :}

Suami mendapat bagian $1 / 4$ dan menerima tiga bagian. Dua anak perempuan mendapat bagian $2 / 3$ dan menerima delapan bagian dan saudara laki-laki sekandung mendapat bagian sisa dan menerima 1 bagian.

Misalkan harta peninggalan Rp 24.000.000 maka pembagiannya adalah : $\frac{H P: R p 24.000 .000}{A M: 12}=R p 2.000 .000$

\begin{tabular}{|c|c|c|c|}
\hline \multicolumn{2}{|c|}{ Ahli waris } & \multicolumn{2}{|c|}{ Bagian yang diterima oleh ahli waris } \\
\hline 1 & زَوْْجْج & 3 bagian x Rp 2.000 .000 & Rp 6.000 .000 \\
\hline 2 & بِنْتُ & 4 bagian x Rp 2.000 .000 & Rp 8.000 .000 \\
\hline 3 & بِنْتُ ت & 4 bagian x Rp 2.000 .000 & Rp 8.000 .000 \\
\hline 4 & أُ خُح شَقَقْيقُ & 1 bagian x Rp 2.000 .000 & Rp 2.000 .000 \\
\hline & & Jumlah & Rp 24.000 .000 \\
\hline
\end{tabular}

8. Contoh: Anak perempuan mendapat dua pertiga bagian

\begin{tabular}{|c|c|c|c|c|c|}
\hline \multicolumn{3}{|c|}{ Ahli waris } & \multicolumn{3}{|c|}{ Asal Masalah (AM): 12} \\
\hline 1 & زَوَجُْْ & suami & $1 / 4$ & 3 & 3 bagian \\
\hline 2 & بِنْتُ & \multirow{2}{*}{ Anak pr. } & \multirow{2}{*}{$2 / 3$} & \multirow{2}{*}{8} & 4 bagian \\
\hline 3 & بِنْتِتُ & & & & 4 bagian \\
\hline 4 & أُجْ لِأَبْ & Saudara lk. sebapak & sisa & 1 & 1 bagian \\
\hline
\end{tabular}

\section{Penjelasan:}


Suami mendapat bagian $1 / 4$ dan menerima tiga bagian. Dua anak perempuan mendapat bagian $2 / 3$ dan menerima de bagian dan saudara perempuan seayah mendapat bagian sisa dan menerima satu bagian.

Seandainya HP Rp 24.000.000, maka suami mendapat Rp 6.000.000, masing-masing anak perempuan mendapatkan bagian sebesar Rp 8.000.000 = Rp 16.000.0000. dan saudara lk. Sebapak mendapat Rp 2.000.000, Jumlah yang diterima oleh masing-masing ahli waris adalah Rp 24.000.000, sesuai dengan HP.

\section{d. Contoh-contoh kasus anak perempuan bergabung dengan anak lelaki}

Anak perempuan dan anak laki-laki bergabung mendapat semua harta peninggalan atau sisanya bagian pasti dengan prosentasi, satu bagian untuk anak perempuan dan dua bagian untuk anak laki-laki

1. Contoh: Bagian anak perempuan bergabung dengan anak laki-laki

\begin{tabular}{|c|c|c|c|c|}
\hline \multicolumn{2}{|c|}{ Ahli waris } & \multicolumn{3}{|c|}{ Asal Masalah (AM) : 4} \\
\hline 1 & زَزوْجْ & $1 / 4$ & 1 & 1 bagian \\
\hline 2 & بِنْتُ & \multirow{2}{*}{ Sisa } & \multirow{2}{*}{3} & 1 bagian \\
\hline 3 & إبنْنُ & & & 2 bagian \\
\hline
\end{tabular}

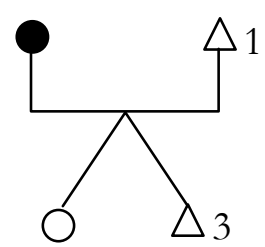

\section{Penjelasan :}

1. Suami mendapat $1 / 4$ dan mendapat satu bagian.

2. Anak perempuan dan laki-laki bergabung mendapat sisa dan mendapat tiga bagian, anak perempuan satu bagian dan anak lakilaki dua bagian.

Misalkan harta peninggalan Rp 24.000.000 maka pembagiannya adalah $: \frac{H P: R p 24.000 .000}{A M: 4}=R p 6.000 .000$

\begin{tabular}{|c|r|c|c|}
\hline \multicolumn{2}{|c|}{ Ahli waris } & \multicolumn{3}{c|}{ Bagian yang diterima oleh ahli waris } \\
\hline \hline 1 & jَgْeٌ & 1 bagian x Rp 6.000 .000 & Rp 6.000 .000 \\
\hline
\end{tabular}




\begin{tabular}{|c|c|c|c|}
\hline 2 & بِنْتُ & 1 bagian x Rp 6.000 .000 & $\mathrm{Rp} \quad 6.000 .000$ \\
\hline 3 & إبنُْْ & 2 bagian x Rp 6.000 .000 & Rp 12.000 .000 \\
\hline \multicolumn{3}{|r|}{ Jumlah } & Rp 24.000 .000 \\
\hline
\end{tabular}

2 Contoh: Bagian anak perempuan bergabung dengan anak laki-laki

\begin{tabular}{|c|c|c|c|c|c|}
\hline \multicolumn{2}{|c|}{$\begin{array}{l}\text { Ahli } \\
\text { waris }\end{array}$} & \multicolumn{3}{|c|}{$\begin{array}{c}\text { Asal Masalah (AM): } \\
8\end{array}$} & \multirow{2}{*}{$\begin{array}{l}\mathbf{H P} \mathbf{R p} \mathbf{8 0 0} \mathbf{j t}: \mathbf{8}=\mathbf{R} \mathbf{p} \mathbf{1 0 0} \mathbf{j t} \\
1 \text { bagian x Rp } 100 \text { jt. }=\mathrm{Rp} \\
100 \text { jt. }\end{array}$} \\
\hline 1 & زَوْجَحةٌ & $1 / 8$ & 1 & 1 bagian & \\
\hline 2 & بِنْتُ & \multirow{4}{*}{ Sisa } & \multirow{4}{*}{7} & 1 bagian & $\begin{array}{l}1 \text { bagian x Rp } 100 \text { jt. }=\mathrm{Rp} \\
100 \text { jt. }\end{array}$ \\
\hline 3 & إِبْنُ & & & 2 bagian & $\begin{array}{l}2 \text { bagian x Rp } 100 \text { jt. = Rp } \\
200 \text { jt. }\end{array}$ \\
\hline 4 & إبْنُْ & & & 2 bagian & $\begin{array}{l}2 \text { bagian } \times \text { Rp } 100 \text { jt. }=\text { Rp } \\
200 \text { jt. }\end{array}$ \\
\hline 5 & إِبْنُ & & & 2 bagian & $\begin{array}{l}2 \text { bagian x Rp } 100 \text { jt. }=\text { Rp } \\
200 \text { jt. }\end{array}$ \\
\hline
\end{tabular}

\section{Penjelasan :}

Bagian istri 1/8 mendapat satu bagian dan sisanya tujuh bagian diberikan pada 5 anak, anak pr. satu bagian dan masing-masing anak lk.mendapat dua bagian.

3. Contoh: Bagian anak perempuan bergabung dengan anak laki-laki

\begin{tabular}{|c|c|c|c|c|c|}
\hline \multicolumn{3}{|c|}{ Ahli waris } & \multicolumn{3}{|c|}{ Asal Masalah (AM) : 6} \\
\hline 1 & أَبٍُّ & Bapak & $1 / 6$ & 1 & 1 bagian \\
\hline 2 & بِنْتُ & Anak pr. & \multirow{3}{*}{ Sisa } & \multirow{3}{*}{5} & 1 bagian \\
\hline 3 & لـابْنُ & Anak laki-laki & & & 2 bagian \\
\hline 4 & إبْنُ & Anak laki-laki & & & 2 bagian \\
\hline
\end{tabular}

\section{Penjelasan :}

1. Bapak mendapat $1 / 6$ dan mendapat satu bagian.

2. Anak perempuan dan laki-laki bergabung mendapat sisa dan mendapat lima bagian, anak perempuan satu bagian dan anak lakilaki dua bagian. 
Misalkan harta peninggalan Rp 24.000.000 maka pembagiannya adalah: $\frac{H P: R p 24.000 .000}{A M: 6}=R p 4.000 .000$ $A M: 6$

\begin{tabular}{|c|c|c|c|c|}
\hline \multicolumn{2}{|c|}{ Ahli waris } & \multicolumn{3}{|c|}{ Bagian yang diterima oleh ahli waris } \\
\hline 1 & أَبُْ & 1 bagian $x$ Rp 4.000 .000 & $\mathrm{Rp}$ & 4.000 .000 \\
\hline 2 & برنْتُ & 1 bagian x Rp 4.000 .000 & $\mathrm{Rp}$ & 4.000 .000 \\
\hline 3 & إِبْنُ & 2 bagian $x$ Rp 4.000 .000 & $\mathrm{Rp}$ & 8.000 .000 \\
\hline 4 & إِبْنُ & 2 bagian $x$ Rp 4.000 .000 & $\mathrm{Rp}$ & 8.000 .000 \\
\hline & & Jumlah & $\mathbf{R p}$ & 24.000 .000 \\
\hline
\end{tabular}

4. Contoh: Bagian anak perempuan bergabung dengan anak laki-laki

\begin{tabular}{|c|c|c|c|c|c|}
\hline \multicolumn{2}{|c|}{$\begin{array}{c}\text { Ahli } \\
\text { waris }\end{array}$} & \multicolumn{3}{|c|}{$\begin{array}{c}\text { Asal Masalah (AM) } \\
: 6\end{array}$} & \multirow{2}{*}{$\begin{array}{l}\mathbf{H P} \mathbf{R p} \mathbf{6 0 0} \mathbf{j t}: \mathbf{6}=\mathbf{R p} \mathbf{1 0 0} \mathbf{j t} \\
\begin{array}{l}\text { bagian x Rp } 100 \text { jt. }=\text { Rp } \\
100 \text { jt. }\end{array}\end{array}$} \\
\hline 1 & أُمٌْمُ & $1 / 6$ & 1 & 1 bagian & \\
\hline 2 & بِنْتُ & \multirow{3}{*}{ Sisa } & \multirow{3}{*}{5} & 1 bagian & $\begin{array}{l}1 \text { bagian x Rp } 100 \text { jt. = Rp } \\
100 \text { jt. }\end{array}$ \\
\hline 3 & إِبْنُ & & & 2 bagian & $\begin{array}{l}2 \text { bagian } x \text { Rp } 100 \text { jt. }=\text { Rp } \\
200 \text { jt. }\end{array}$ \\
\hline 4 & إِبْنُ & & & 2 bagian & $\begin{array}{l}2 \text { bagian } x \text { Rp } 100 \text { jt. }=\text { Rp } \\
200 \text { jt. }\end{array}$ \\
\hline \multicolumn{5}{|c|}{ Jumlah } & $=R p 600$ jt. \\
\hline
\end{tabular}

\section{Penjelasan :}

Ibu mendapat $1 / 6$ mendapat satu bagian dan sisanya lima bagian diberikan pada 3 anak, anak pr. satu bagian dan masing-masing anak lk.mendapat dua bagian.

5. Contoh: Bagian anak perempuan bergabung dengan anak laki-laki

\begin{tabular}{|c|c|c|c|c|c|}
\hline \multicolumn{3}{|c|}{ Ahli waris } & \multicolumn{3}{|c|}{ Asal Masalah (AM) : 6} \\
\hline 1 & جَدُّ & Kakek & $1 / 6$ & 1 & 1 bagian \\
\hline 2 & بِنْتُ & Anak pr. & \multirow{2}{*}{ Sisa } & \multirow{2}{*}{5} & 1 bagian \\
\hline 3 & إِبْنُ & Anak laki-laki & & & 2 bagian \\
\hline
\end{tabular}




\begin{tabular}{|l|l|l|l|l|l|}
\hline 4 & إبنن & Anak laki-laki & & & 2 bagian \\
\hline
\end{tabular}

\section{Penjelasan :}

1. Kakek mendapat $1 / 6$ dan mendapat satu bagian.

2. Anak perempuan dan laki-laki bergabung mendapat sisa dan mendapat lima bagian, anak perempuan satu bagian dan anak lakilaki dua bagian.

Misalkan harta peninggalan Rp 24.000.000 maka pembagiannya adalah : $\frac{H P: R p 24.000 .000}{A M: 6}=R p 4.000 .000$

\begin{tabular}{|c|c|c|c|c|}
\hline \multicolumn{2}{|c|}{ Ahli waris } & \multicolumn{3}{|c|}{ Bagian yang diterima oleh ahli waris } \\
\hline 1 & جَرَدُّ & 1 bagian x Rp 4.000 .000 & $\mathrm{Rp}$ & 4.000 .000 \\
\hline 2 & 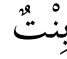 & 1 bagian $x$ Rp 4.000 .000 & $\mathrm{Rp}$ & 4.000 .000 \\
\hline 3 & 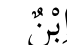 & 2 bagian $x \operatorname{Rp} 4.000 .000$ & $\mathrm{Rp}$ & 8.000 .000 \\
\hline 4 & لـ بْنْ & 2 bagian $x$ Rp 4.000 .000 & $\mathrm{Rp}$ & 8.000 .000 \\
\hline \multicolumn{3}{|r|}{ Jumlah } & $\mathbf{R p}$ & 24.000 .000 \\
\hline
\end{tabular}

6. Contoh: Bagian anak perempuan bergabung dengan anak laki-laki

\begin{tabular}{|c|c|c|c|c|c|}
\hline \multicolumn{2}{|c|}{$\begin{array}{c}\text { Ahli } \\
\text { waris }\end{array}$} & \multicolumn{3}{|c|}{ Asal Masalah (AM) :6 } & $\begin{array}{c}\text { HP Rp } 600 \text { jt : } 6=R p 100 \\
\text { jt }\end{array}$ \\
\hline 1 & 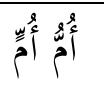 & $1 / 6$ & 1 & 1 bagian & $\begin{array}{l}1 \text { bagian x Rp } 100 \text { jt. = Rp } \\
100 \text { jt. }\end{array}$ \\
\hline 2 & بِنْت & \multirow{3}{*}{ Sisa } & \multirow{3}{*}{5} & 1 bagian & $\begin{array}{l}1 \text { bagian x Rp } 100 \text { jt. }=\text { Rp } \\
100 \text { jt. }\end{array}$ \\
\hline 3 & إِبْنُ & & & 2 bagian & $\begin{array}{l}2 \text { bagian } \times \text { Rp } 100 \text { jt. }=\text { Rp } \\
200 \text { jt. }\end{array}$ \\
\hline 4 & إبـْنُ & & & 2 bagian & $\begin{array}{l}2 \text { bagian x Rp } 100 \text { jt. = Rp } \\
200 \text { jt. }\end{array}$ \\
\hline \multicolumn{5}{|c|}{ Jumlah } & 600 it $\quad=R p$ \\
\hline
\end{tabular}

\section{Penjelasan :}

Nenek mendapat 1/6 mendapat satu bagian dan sisanya lima bagian diberikan pada 3 anak, anak pr. satu bagian dan masingmasing anak lk.mendapat dua bagian. 
7. Contoh: Bagian anak perempuan bergabung dengan anak laki-laki

\begin{tabular}{|c|c|c|c|c|c|}
\hline \multicolumn{3}{|c|}{ Ahli waris } & \multicolumn{3}{|c|}{ Asal Masalah (AM) : 6} \\
\hline 1 & جحَدُّ & Kakek & $1 / 6$ & 1 & 1 bagian \\
\hline 2 & بِنْتِتُ & Anak pr. & \multirow{4}{*}{ Sisa } & \multirow{4}{*}{5} & 1 bagian \\
\hline 3 & بِنْتُ & Anak pr. & & & 1 bagian \\
\hline 4 & بِنْتُتُ & Anak pr. & & & 1 bagian \\
\hline 5 & إِبْنُ & Anak laki-laki & & & 2 bagian \\
\hline
\end{tabular}

\section{Penjelasan :}

1. Kakek mendapat $1 / 6$ dan mendapat satu bagian.

2. Anak perempuan dan laki-laki bergabung mendapat sisa dan mendapat lima bagian, anak perempuan satu bagian dan anak lakilaki dua bagian.

Misalkan harta peninggalan Rp 24.000.000 maka pembagiannya adalah : $\frac{H P: R p 24.000 .000}{A M: 6}=R p 4.000 .000$

\begin{tabular}{|c|c|c|c|c|}
\hline \multicolumn{2}{|c|}{ Ahli waris } & \multicolumn{3}{|c|}{ Bagian yang diterima oleh ahli waris } \\
\hline 1 & 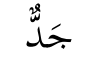 & 1 bagian x Rp 4.000 .000 & $\mathrm{Rp}$ & 4.000 .000 \\
\hline 2 & بِنْتُ & 1 bagian x Rp 4.000 .000 & Rp & 4.000 .000 \\
\hline 3 & بِنْتُ & 1 bagian x Rp 4.000 .000 & Rp & 4.000 .000 \\
\hline 4 & بِنْتُ & 1 bagian x Rp 4.000 .000 & Rp & 4.000 .000 \\
\hline 5 & إِبْنُ & 2 bagian $x$ Rp 4.000 .000 & Rp & 8.000 .000 \\
\hline & & Jumlah & $\mathbf{R p}$ & 24.000 .000 \\
\hline
\end{tabular}

8. Contoh: Bagian anak perempuan bergabung dengan anak laki-laki Ahli waris

$$
\text { Asal Masalah (AM) :6 HP Rp } 600 \text { jt : } 6=\mathrm{Rp} 100 \mathrm{jt}
$$




\begin{tabular}{|c|c|c|c|c|c|}
\hline 1 & 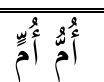 & $1 / 6$ & 1 & 1 bagian & 1 bagian $x$ Rp 100 jt. = Rp 100 jt. \\
\hline 2 & بِنْتِ & \multirow{4}{*}{ Sisa } & \multirow{4}{*}{5} & 1 bagian & 1 bagian x Rp 100 jt. = Rp 100 jt. \\
\hline 3 & بِنْتِ & & & 1 bagian & 1 bagian x Rp 100 jt. = Rp 100 jt. \\
\hline 4 & بِنْتُ & & & 1 bagian & 1 bagian $\mathrm{x}$ Rp $100 \mathrm{jt.}=\mathrm{Rp} 100 \mathrm{jt}$. \\
\hline 5 & إبِنُْ & & & 2 bagian & 2 bagian x Rp 100 jt. = Rp 200 jt. \\
\hline \multicolumn{5}{|c|}{ Jumlah } & $=R p 600$ jt. \\
\hline
\end{tabular}

\section{KESIMPULAN}

Dari paparan di atas dapat disimpulkan srbagai berikut:

1. Bagian anak perempuan dalam pasal $176 \mathrm{KHI}$ mendapat separoh bagian dengan syarat seorang dan mayat tidak meninggalkan anak laki-laki. Apabila meninggalkan anak laki-laki maka bergabung, anak perempuan mendapat satu bagian dan anak laki-laki mendapat dua bagian.

Sedangkan kasusnya dalam pembagian harta peninggalan (HP), bersamaan suami, istri, bapak, ibu, kakek, nenek, saudara sekandung perempuan atau laki-laki, saudara seayah perempuan atau laki-laki, saudara seibu perempuan atau laki, atau paman sekandung maupun paman seayah.

2. Bagian anak perempuan dalam pasal $176 \mathrm{KHI}$ mendapat dua pertiga bagian dengan syarat dua orang atau lebih dan mayat tidak meninggalkan anak laki-laki. Apabila meninggalkan anak laki-laki maka bergabung, anak perempuan mendapat satu bagian dan anak laki-laki mendapat dua bagian

Sedangkan kasusnya dalam pembagian harta peninggalan (HP), bersamaan suami, istri, bapak, ibu, kakek, nenek, saudara sekandung perempuan atau laki-laki, saudara seayah perempuan atau laki-laki, saudara seibu perempuan atau laki, atau paman sekandung maupun paman seayah.

3. Bagian anak perempuan dalam pasal $176 \mathrm{KHI}$ bergabung dengan anak laki-laki dan anak perempuan mendapat satu bagian sedangkan anak laki-laki mendapat dua bagian 
Sedangkan kasusnya dalam pembagian harta peninggalan (HP), hanya bersamaan suami, istri, bapak, ibu, kakek, atau nenek. Seandainya ditambah ahli waris yang percuma sebab dihalangi oleh anak laki-laki

4. Untuk kisaran harta peninggalan (HP) dalam kasusu di atas, itu hanya menyesuaikan dengan Asal Masalah (AM) bisa saja disesuaikan dengan harta Peninggalan (HP) yang sesungguhnya, tapi setidaknya sudah muncul rumusan bahwa Asal Masalah (AM) itu dipakai untuk membagi Harta Peninggalan (HP) kemudian hasilnya dikalikan dengan bagian yang diterima oleh ahli waris.

\section{DAFTAR PUSTAKA}

\section{A. Kelompok Al-Qur'an dan Tafsir}

Al-Marâghi, Ahmad Mustafa. 1974. Tafsìr Al-Maräghi, juz 4.

Al-Razi, Muhammad Fakhruddin. t.th. Tafsìr Fabr Al-Räæị, Juz 6 dan 11. Beirut: Dar Al-Fikr.

Al-Suyuti, Jalaluddin. t.th. Al-Dur Al-Mantsur Fi Al-Ta wil bi AlMa`tsur. Beirut: Dar Al-Fikr.

Departemen Agama Republik Indonesia. 1971. Al-Qur'an dan Terjemahannya. Jakarta: Yayasan Penyelenggara / Penterjemah Al-Qur'an.

Quthub, Sayyid. 2001. Tafsì fi Zhiläl Al-Qur'an, Al-Mujallad Awwal dan Tsani. Beirut: Dar Al-Syuru'.

\section{B. Kelompok Hadist}

Al-'Asqalani, Ibn Hajar. t.th. Bulügh Al-Marâm. Surabaya: Al-Hidayah. Al-Bukhāri. t.th. Matn Al-Bukhāri, juz. 4. Singapura: Maktabah wa Mathba'ah Sulaiman.

Al-Syaukani, Muhammad bin Ali. t.th. Nail Al-Authâr, Juz 8. Beirut: Dar Al-Fikr.

\section{Kelompok Fiqih}

Al-Fauzani, Salih bin Fauzan bin Abdullah. t.th. Al-Tahqîqah AlMardiyyah Fi Al-Mabâbits Al-Fardiyyah. Beirut: Dar Al-Fikr.

Al-Hadrami, Sa'id bin Said Nabhan. t.th. Iddat Al-Fâridh. Surabaya: Salim Sa'id bin Said Nabhan. 
Al-Lahimi, Abd Al-Karim bin Muhammad. 1986. Al-Farâ'idh. Riyadh: Matabah Al-Ma'arif.

Al-Mahâmi, Shabahi Mahmashâni. 1967. Al-Mabâdi Al-Syar'iyyah wa Al-Qânûniyyah. Beirut: Dar Al-'Ilm.

Al-Sahi, Syauqi Abduh. 1988. Abkâm Al-Mawârits. Damaskus: Dar Hikmah.

Al-Shabuni, Muhammad bin Ali. 1979. Al-Mawârits Fi Al-Syariat AlIslamiyah. Beirut: Dar Al-Fikr.

Al-Zuhayli, Wahbah. 2001. Al-Farâ'idh wa Al-Mawârits wa AlWashâya. Damaskus: Dar Al-Qalam.

Badawi, Syansuri. t.th. 'Ilm Al-Mawârits. Jombang: Tebuireng.

Makhluf, Muhammad Husen. 1976. Al-Mawârits Fi Al-Syarỉab AlIslamiyyah. Riyadh: Matba'ah Al-Madani.

Muhyidin, Abd Al-Hamid. 1984. Abkâm Al-Mawârits Fi Al-Syari'ah Al-Islamiyyah 'Ala Madhbab Al-A imah Al-Arba'ah. Beirut: Dar Al-Fikr.

Muslim, Musthafa. 1992. Mabâhits Fi Tlm Al-Mawârits. Jeddah: Dar Al-Munarah.

Musthafa. 2004. Al-Rahabiyyah 'Ilm Al-Farâidh. Damaskus: Dar AlQalam. 